\title{
Murens fald - tyve år efter
}

Uffe Østergård

\section{Nationalismens spøgelse er stadig ikke forsvundet, og langt fra alle konflikter i og omkring Europa er løst, men overordnet set er der alligevel grund til at glæde sig her tyve år efter kommunismens og Murens fald}

1989 var et begivenhedsrigt år. I første omgang erkendte jeg dog ikke rigtigt rækkevidden af omvæltningerne i Øst- og Centraleuropa, fordi jeg sammen med mange andre historikere var fuldt optaget af at forberede 200-året for den franske revolution. Begivenheden markeredes i Frankring med et kæmpestort internationalt symposium på Sorbonne under protektion af præsidenten François Mitterrand (1916-1996) i første halvdel af juli.

Det var interessant at deltage i fejringen af denne hellige begivenhed i fransk politisk kultur. Der blev holdt mange, lange og salvelsesfulde taler om revolutionens betydning for menneskeheden i almindelighed og menneskerettighederne i særdeleshed. Retrospektivt kom juli 1989 imidlertid snarest til at markere afslutningen af en epoke hvor man uden tøven kunne fremhæve revolu- tionen som et civilisatorisk fremskridt.

Der var enkelte kritiske røster; bl.a. var vi tre danske som plæderede for at de fredelige dansk-norske reformer i 1780'erne under den oplyste, såkaldt 'opinionsstyrede enevælde'reelt repræsenterede et væsentligt større fremskridt end den voldelige omvæltning af det politiske system i Frankrig, der reelt indebar en fastfrysning af ejendomsforholdene på landet helt til begyndelsen af 1960'erne. En fastfrysning af en uøkonomisk produktion der nok har bevaret en høj kvalitet af velsmagende landbrugsprodukter, men for en pris der i høj grad betales af de øvrige medlemmer af EU gennem landbrugsordningerne. Efter indlægget blev vi belært af franske kolleger om at vi måtte have udtrykt os forkert på fransk, siden vi var kommet til at sige at den franske revolu- 
tion ikke var det mest progressive fænomen i europæisk historie. Det blev til en interessant og ophedet meningsudveksling, for det var jo netop hvad vi mente.

\section{Revolutioner i miskredit}

I dag er kritikken af terroren og de mange utilsigtede bivirkninger af revolutionen alment dominerende blandt historikere, efterhånden også i Frankrig, i hvert fald uden for de allermest dogmatiske kredse. Men dengang var det en så minoritær position, at den ledende fortaler for kritikken, François Furet (1927-97), slet ikke deltog i festlighederne.

Denne ændring af vurderingen af revolutioner i almindelighed og den store franske i særdeleshed skyldes mange forhold. Men vigtigst er at revolutioner er kommet i miskredit, også blandt venstreorienterede. Det var allerede begyndt med den islamiske revolution i Iran i 1979 der demonstrerede, at revolutioner også kan føre til religiøst tyranni. Endnu vigtigere var dog at udviklingen $\mathrm{i}$ Sovjetunionen og det kommunistiske Østeuropa gjorde det klart, at kommunismen havde ført til et totalitært diktatur, ja havde været det fra begyndelsen, også hos den Lenin (1870-1924) som venstreorienterede har prøvet at redde fra identifikation med stalinismens terror.

Det er efterhånden blevet klart at terroren og koncentrationslejrene begyndte med Lenin og ikke først med Stalin (1879-1953), som mange slog sig til tåls med at tro efter Nikita Khrusjtjovs (1894-1971) afsløringer på den hemmelige partikongres i 1956. Kommunisme var ikke elektrificering kombineret med kommunistpartiet som Lenin sagde, men indebar også politistat og terror mod alle anderledes tænkende som bl.a. Niels Erik Rosenfeldt overbevisende har påvist i sin Lenin-biografi fra 2008.

På baggrund af den erkendelse blev det nærliggende også at stille kritiske spørgsmål til den positive forståelse af den franske revolution som hidtil havde domineret blandt vestlige liberale og socialister. Det var hvad Furet gjorde i en lang række indflydelsesrige værker. Først essaysamlingen Penser la Révolution française (At tænke den franske revolution) fra 1978, siden med direkte politisk sigte i hovedværket Le Passé d'une illusion, essai sur l'idée communiste au XXe siècle 1995 (The Passing of an Illusion: The Idea of Communism in the Twentieth Century 1999). Dette værk af en tidligere overbevist kommunist har sammen med Kommunismens Sorte Bog om ofrene for denne totalitære politiske ideologi ændret billedet af kommunismen for altid.

\section{Ungarns åbning}

Nytolkningen var på vej længe før, men blev hjulpet på vej af de politiske omvæltninger i Sovjetunionen og Øst- og Centraleuropa. For mens 
vi mange hundrede akademikere sad og svedte i Sorbonnes auditorier, studerede militærparaden på Champs Elyseés og deltog i festen i Paris 14. juli, faldt de kommunistiske regimer ét efter ét.

2. maj 1989 havde den kommunistiske regering i Ungarn besluttet at det ikke var dens opgave at redde DDR fra landets egne indbyggere, og derfor åbnede de Jerntæppet til $\emptyset_{\text {strig for tusinder af flygtende }}$ DDR-borgere ved simpelthen fysisk at klippe hul i det elektriske hegn ved grænsen til Østrig. Denne beslutning var kulminationen af en række demokratiske reformer som et yngre lederskab i det kommunistiske parti i Ungarn havde gennemført for at komme ud af den stivnede situation, som János Kádár (1912-1989) havde bragt landet i.

Kádár havde ledet Ungarn siden nedkæmpelsen af opstanden i 1956 og havde en tid været populær som garant for den såkaldte 'gullaschkommunisme'. Velfærden var imidlertid blevet betalt med vestlige lån, og det stod klart for de yngre teknokrater at landet var vej til fallit. Derfor indledte de en reformproces, stærkt inspireret af Mikhail Gorbatjov (f. 1931) i Sovjetunionen.

Symbolsk besluttedes det at genbegrave helten fra 1956, Imre Nagy (1896-1958), på Martyrernes Plads i det centrale Budapest. Da Ungarn efter Anden Verdenskrig blev okkuperet af Sovjetunionen, var Nagy vendt tilbage til Ungarn fra Sovjet- unionen som medlem af den sovjetiske marionetregering. Han blev dog hurtigt skeptisk over for Sovjetunionens dominans og forsøgte da han 1953 blev premierminister at distancere sig fra den. Det førte til hans afsættelse i 1955. Da ungarerne året efter gjorde oprør mod Sovjetunionen blev Nagy igen premierminister. Han forsøgte forgæves at få hjælp fra Vesten, men måtte søge asyl på den jugoslaviske ambassade efter at sovjetiske tanks havde knust opstanden. Han blev lovet frit lejde, men blev arresteret, henrettet og begravet i hemmelighed i 1958.

Efter en officiel statsbegravelse 14 . juni med titusindvis af deltagere i procession gennem det centrale Budapest blev der opstillet en statue af ham på Martyrpladsen.

\section{Polske rundbordssamtaler}

Ungarns åbning af Jerntæppet tillod tusinder af DDR-borgere at flygte til Vesten. Det skete samtidig med de såkaldte rundbordssamtaler i Polen mellem general Wojciech Jaruzelskis (f. 1923) kommunistiske diktatur og den opposition han havde undertrykt med et militærkup i december 1981. Forhandlingerne resulterede $\mathrm{i}$ at flere partier fik lov til at stille ved valgene til Sejmen (parlamentet) ved et delvis frit valg. Oppositionen der var samlet omkring fagforbundet Solidarnosc, var grundlagt i september 1980 under ledelse af Lech Wałęsa (f. 1943) som en bred anti- 
kommunistisk bevægelse omfattende alt lige fra den katolske kirke til liberale intellektuelle og socialister som historikeren Adam Michnik (f. 1946), indtil 2004 indflydelsesrig chefredaktør for Polens største avis Gazeta Wyborcza.

Den ikke-voldelige modstandslinje var oprindelig blevet formuleret af de intellektuelle dissidenter i KOR (Komitet Obrony Robotników, Komitéen til forsvar for arbejderne). Komitéen eksisterede fra 1976 til 1981 og formulerede mange af de idéer som sejrede med den demokratiske udvikling i Polen i 1989. Den var blevet oprettet for at forsvare de arbejdere der efter omfattende uroligheder på fabrikker i Warszawa og Radom i juni 1976 blev udsat for regimets brutale forfølgelser.

KOR hjalp i første omgang arbejderne finansielt og juridisk. Da arbejderne i 1977 blev løsladt, udvidede komitéen sit arbejde. I ånden fra den internationale Helsinki-slutakt fra 1975 som den polske regering var medunderskriver af, ville KOR bekæmpe politisk, religiøs og racemæssig undertrykkelse, bl.a. ved at indsamle dokumentation for retsbrud. Selv om komitéen var illegal arbejdede KOR helt åbent, og dens appeller til regering, parti og samfund var underskrevet af medlemmerne.

\section{Solidarnosc}

Samarbejdet mellem intellektuelle og arbejdere vakte stor uro i Kommunistpartiet, der anså KOR-medlemmerne for regimets farligste fjender. KOR kæmpede for frie fagbevægelser og var medgrundlægger af Solidarnosc i 1980. Komitéen opløste sig selv i 1981 kort før hele demokratibevægelsen blev undertrykt af et militærkup. Militærstyret formåede imidlertid ikke at rette op på den økonomiske udvikling og blev gradvis tvunget til at forhandle med oppositionen. April 1989 førte det til at Solidarnosc fik lov til at stille op ved et delvis frit parlamentsvalg. Det resulterede $i$ at dets kandidater vandt en knusende sejr, hvilket igen ledte til en serie af antikommunistiske omvæltninger i Central- og Østeuropa. I slutningen af august 1989 kom en koalitionsregering ledet af Solidarnosc til magten. Overgangen til demokrati kronedes i december 1990 med valget af den forhenværende elektriker og fagforeningsleder fra Gdansk, Lech Wałęsa til præsident som afløser for Jaruzelski.

Polens rolle er ikke glemt i dag, selv om polakkerne har følt sig noget oversete $i$ al fejringen af åbningen af Muren mellem Øst- og Vestberlin 9. november 1989, en åbning der blev begyndelsen til enden for det kommunistiske DDR og foreningen af Øst- og Vesttyskland i 1990. Det er vigtigt at erindre at åbningen af Muren kun var ét, om end et yderst vigtigt, led i den serie af omvæltninger i Øst- og Centraleuropa, der i dag har ført til at flertallet af 
de tidlige sovjetiske satellitstater er blevet medlemmer af såvel EU som NATO, samtidig med at Sovjetunionen er opløst, og de tidligere Sovjetrepublikker forvandlet til mere eller mindre selvstændige stater. Ja de tre baltiske lande er endda blevet medlemmer af EU i $2004 \mathrm{og}$ af NATO, selv om russerne officielt opfatter dem som en del af det 'nære udland', omfattende alle de gamle Sovjetrepublikker fra Ukraine til Georgien og Centralasien.

\section{Reform på kinesisk}

Omvæltningerne i det kommunistiske Østeuropa gjorde indtryk overalt i verden. Mest i det kommunistiske Kina hvor de fik lederskabet til den 4. juni 1989 at slå hårdt ned på en studenterdemonstration for mere demokrati på den Himmelske Freds Plads. Tiananmen betyder på kinesisk 'Porten til den himmelske fred' og er navnet på den massive sydlige hovedport til det tidligere kejserpalads i Beijing og samtidig navnet på denne centrale plads.

Den var anlagt i $1651 \mathrm{og}$ udvidet til sit nuværende omfang i 1958, samtidig med et stort 'Monument for Folkets Helte', mens 'Folkets Store Hal' blev bygget på vestsiden. Mod syd afsluttes pladsen af den massive Qianmen (Forport) fra 1400-tallet. I 1977 opførtes Mao Zedongs mindehal der rummer Maos balsamerede legeme. Tiananmen er det kommunistiske styres mest cen- trale politiske mindested, der siden 1919, hvor pladsen for første gang var ramme om store studenterdemonstrationer, har været et symbol på folkets kamp for frihed.

Demonstrationen indledtes 14 . april i anledning af Hu Yaobangs (1915-89) død. Hu havde indtil sin afsættelse i 1987 stået for en pro-demokrati- og anti-korruptionslinje som de protesterende ønskede fortsat. I den anledning af hans begravelse samledes op mod en million sørgende. Deltagerne rakte fra desillusionerede partimedlemmer og trotskister til tilhængere af fri markedsøkonomi.

Demonstrationen fortsatte i syv uger, indtil tanks blev sendt ind på pladsen og ryddede den med mange hundrede dræbte til følge. I kølvandet på indgrebet slog styret hårdt ned på alle tilhængere af demokratibevægelsen og udviste udenlandske korrespondenter. Medlemmer af partiet der havde ytret sympati med de demonstrerende, blev udrenset, og adskillige højt placerede partimedlemmer blev sat i husarrest, herunder generalsekretæren Zhao Ziyang (1919-2005).

Hermed slog Kina entydigt ind på en autoritær vej. Men samtidig fortsattes de økonomiske reformer i hidtil uset tempo med det resultat at Kina i dag, tyve år senere, af mange betragtes som det mest succesrige eksempel på en ny samfundsform som kaldes 'autoritær markedsøkonomi'. Den kinesiske ledelse havde 
lært af de mislykkede sovjetiske reformer med perestrojka og glasnost at det var klogere at begynde med økonomien - hvilket i parentes bemærket viser at de var bedre marxister end juristen og leninisten Gorbatjov. Hvordan det nu end forholder sig med de kinesiske lederes marxisme, er der næppe nogen som, uanset hvor kritisk man er over for undertrykkelsen af oppositionen og behandlingen af Tibet, Xinjiang og Taiwan, ikke vil indrømme at strategien har været mere succesrig end den sovjetiske.

\section{Mislykket sovjetisk strategi}

Trods al den interesse Mikhail Gorbatjovs forsøg på at reformere det sovjetiske system vakte i Øst såvel som Vest mislykkedes de. Det skyldtes formentlig kombinationen af dybden af den økonomiske krise der havde ramt alle kommandoøkonomierne i Øst, samt at Gorbatjov som en god tilhænger af Lenins lære oprigtigt troede at Sovjetunionen havde løst det 'nationale spørgsmål' og haft held med at skab et nyt 'sovjetisk menneske' under sloganet 'national i form, kommunistisk $i$ indhold'. Så sent som 2. november 1987 udtalte Gorbatjov med selvfølelse i et møde i centralkomitéen: "Kammerater, vi er i vores gode ret til at hævde at vi har klaret nationalitets-spørgsmålet." (citeret efter Hélène Carrère d'Encausse, De sorjetiske minoriteter, 1991 s. 7).
Og sådan så det faktisk ud, ikke bare i det russiske centrum, men overalt i republikkerne. Under Leonid Breznjevs (1906-1982) stagnationsperiode i 1970'erne, hvor det vigtige ikke var realiteterne, men hvordan virkeligheden tog sig ud, syntes den ligeberettigede føderalisme ligefrem at trives i bedste velgående i Sovjetunionen. I de kaukasiske og centralasiatiske republikker strømmede ungdommen som følge af den officielle nationale begunstigelsespolitik i stil med den amerikanske affirmative action ind på universiteterne i langt større tal end russerne. Ministerierne blev i stadig højere grad bemandet med indfødte, samtidig med at russerne i stigende tal forlod Aserbajdsjan, Kasakhstan og de Centralasiatiske republikker. Breznjev var i Centralkomitéen omgivet af nære medarbejdere fra de ikke-russiske republikker, hvor især Kunajev fra Kasakhstan og Rasjidov fra Usbekistan øvede betydelig indflydelse.

Men alt var ikke godt. Det afslørede Gorbatjov, da han rettede glasnosts afslørende lys mod korruption, slendrian og klientelisme i de ikke-russiske såvel som i de russiske republikker. Ifølge den franske ruslandshistoriker Hélène Carrère d'Encausse's (f. 1929) analyse gik det så galt for Gorbatjov, netop fordi han var moderne og vestligt indstillet. Han troede naivt, lige som det store flertal i Vesten, at problemerne i Sovjetunionen var af økonomisk 
og organisatorisk natur. Hvis man fjernede hindringerne for $ø$ konomien ville samfundet modernisere sig selv. Derfor slog han ned på korruption og udygtighed, fyrede stribevis af inkompetente ledere og erstattede dem med dygtige etniske russere fra sin egen generation. Men derved ødelagde han utilsigtet de komplicerede nationale og etniske balancer som var etableret under Bresjnev.

I periferien blev det opfattet som et signal til russificering, da han fyrede den mangeårige førstesekretær i Kasakhstan, Dinmukhamed Kunajev (1912-1993, medlem af Politbureauet fra 1971 til 1987, for korruption og erstattede ham med en ukompromitteret russer, Gennadij Kolbin (1927-1998). At Kolbin var dygtig og ubestikkelig var fuldstændig underordnet for de lokale, der opfattede udskiftningen som et brud på fyrre års selvforvaltning.

Kolbin holdt kun til juni 1989 som førstesekretær, hvorefter han blev afløst af kasakhen Nursultan Azarbajev (f. 1940), der i dag leder Kasakhstan nærmest enevældigt. Studenterne i hovedstaden Alma Ata, nu Almaty (men ikke længere hovedstad i Kasakhstan, det er Astana i midten af landet), gik på gaden i demonstrationer der hurtigt udartede til gadekampe. Netop fordi han ville skabe et moderne og økonomisk velfungerende samfund, fremprovokerede Gorbatjov opløsningen af unionen og bragte hele det sovjetiske imperium til fald. Opløsningen blev uundgåelig efter at Gorbatjov i Europa-Parlamentet i Strasbourg 6. juli 1989 erklærede at han ikke ville modsætte sig reformer i Østeuropa.

\section{Kommunismens fald}

Resultatet blev kommunismens fald i Øst- og Centraleuropa i 1989, foreningen af Tyskland 9. oktober 1990 og opløsningen af Sovjetunionen i december 1991 på initiativ af Boris Jeltsin (f. 1931), der som præsident i den Føderative Russiske Republik tog initiativ til at opløse Unionen af Socialistiske Sovjet Republikker, USSR.

Denne multinationale stat var blevet oprettet i 1922, da de sovjetiske ledere måtte erkende at verdensrevolutionen lod vente på sig. I stedet konsoliderede de med basis i Moskva det meste af det gamle zar-Rusland som en føderation af formelt selvstændige stater.

På papiret var der tale om et ægte statsforbund som resten af verden havde mulighed for at melde sig ind i. Ukraine og Hviderusland (Belarus) var nominelt så selvstændige at de fik sæde i Folkenes Forbund og siden i efterfølgeren FN.

Under Stalins terrorregime og den russisk-nationalistiske ideologiske oprustning i 1930'erne blev det imidlertid klart at Sovjetunionen var en fortsættelse af det førrevolutionære russiske imperium, blot med andre midler. Den afgørende faktor var det centralistisk organiserede 
kommunistiske parti hvor alle var lige underordnede efter princippet om 'demokratisk centralisme', samt den centralstyrede planøkonomi.

Set i den store sammenhæng blev Oktober-revolutionens primære historiske rolle således at udskyde opløsningen af det russiske imperium i godt 70 år fra 1917 til 1991, mens Første Verdenskrig førte til opløsningen af Ruslands to konkurrenter, Østrig-Ungarn og det Osmanniske Rige.

Den Russiske Føderation som vi normalt kalder Rusland er en fortsættelse af den Russiske Sovjetiske Føderale Socialistiske Republik, RSFSR. Denne republik var langt den største, men altså ikke den eneste $\mathrm{i}$ Sovjetunionen. RSFSR blev organiseret i 1919-20 af de områder bolsjevikkerne havde kontrol over. Resten af zar-tidens besiddelser blev gradvis undertvunget militært og indlemmet som egne republikker. Særligt blodigt gik det for sig i Georgien februar 1921 og i Centralasien.

I det sidste område udkæmpede sovjetiske tropper i 1920'erne en veritabel kolonikrig mod muslimske oprørere, de såkaldte basmatji ('røvere'). En indsats som sovjetiske film siden glorificerede i en række 'easterns', hvor teknologisk overlegne russere med tanks og fly bekæmpede primitive og lumske muslimer på stepperne. Generobringen kronedes i 1940 med indlemmelsen af de baltiske stater, det østlige Polen og Moldavien i overensstemmelse med Mo-
lotov-Ribbentrop-pagten fra august 1939.

I 1945 anerkendte resten af verden stiltiende denne uret, som først blev gjort god igen med opløsningen af USSR. Danmark anerkendte i modsætning til andre vestlige lande aldrig formelt indlemmelsen af de tre baltiske stater, men i praksis gjorde det først en forskel, da balterne i 1990 krævede selvstændighed, og Uffe Ellemann-Jensen (f. 1941) udnyttede det til uofficielt at støtte balternes frihedskamp. Den førnævnte franske historiker Hélène Carrère d'Encausse havde i en berømt bog fra 1978, L'empire éclaté, forudsagt opløsningen af Unionen.

Det fik hun ret i, men ikke pga. et oprør i det muslimske Centralasien som hun regnede med, men pga. oprøret i de baltiske lande. Så var den svenske historiker Kristian Gerner (f. 1939) tættere på med sin forudsigelse fra 1981 om Sovjetunionens opløsning pga. en kombination af økologiske problemer og nationale opstande. At forudsigelsen var lige ved at koste ham jobbet på Lunds Universitet for 'fornærmelse af venligtsindet nabostat' siger noget om såvel Sverige som situationen før 1989.

Den inderste ring af det gamle russiske imperium overlevede imidlertid i form af den Russiske Føderation. Denne uhyre statsdannelse strækker sig geografisk fra Kaliningrad ved Østersøen til Vladivostok ved Stillehavet og fra Ishavet i nord 
til Sortehavet i syd. Den omfatter størsteparten af det eurasiske fastland uden respekt for den grænse mellem Europa og Asien ved Uralbjergene som talrige europæiske ideologer har proklameret uden viden om, hvor ringe betydning disse lave, skovbevoksede bjerge i grunden har.

Ural som grænse mellem Europa og Asien blev først formuleret af en tysk-svensk officer i russisk tjeneste i 1730, Philip Johan von Strahlenberg. Strahlenberg var blevet taget til fange af russerne ved det store svenske nederlag ved Poltava (i Ukraine) 1709 og tilbragte fangenskabet i Sibirien. Efter sin tilbagekomst til Sverige udsendte han i 1730 værket, Das nord- und östliche Theil von Europa und Asia, hvor grænsen ved Ural blev slået fast.

At denne grænsedragning siden er indgået i den folkelige bevidsthed, ændrer ikke ved at den går midt igennem en stat der nok er multinational, men om muligt mere russisk domineret end Sovjetunionen.

Uden at gå nærmere ind på konflikten om Tjetjenien er det vigtigt at fastslå at staten er en føderation af mange lande og folk, hvoraf mange har vidt udstrakt autonomi.

Borgerne i den Russiske Føderation kaldes rossijane (af Rossija), uanset om de er tatarer, ukrainere, russere eller noget helt andet. Etniske russere derimod hedder ruski (af Rus). Borgernes identitet er imidler- tid ikke russisk i etnisk forstand, sådan som mange danske - og hvad værre er, også mange russere - er tilbøjelige til at tro.

Folkeretsligt set er Rusland en forbundsstat, hvor republikker som Tatarstan har en meget høj grad af selvstændighed. Det markeres symbolsk med Europas største moské i midten af Kreml i Kazan fra 2005, nu dog modsvaret af en pragtfuld ortodoks katedral. At etniske russere så i praksis helt og aldeles dominerer føderationen og uden blusel taler om Rusland og russere (ruski), også når de taler på vegne af de i etnisk forstand ikke-russiske statsborgere, er anden sag.

\section{Gorbatjovs rolle}

Gorbatjovs og siden Jeltsins reformer markerede et delvis brud med den sovjetiske politistats moderniseringsforsøg. Men ikke nødvendigvis med tendenser i den lange russiske historie fra 1500-tallet til i dag. På en måde minder Gorbatjovs hensigter og metoder slående om moderniseringsforsøgene under zar Aleksander II (1818-81) der i 1861 ophævede livegenskabet. Det gælder helt ned til terminologien med $z a$ konnost (lovlighed) og glasnost (åbenhed).

For begge reformatorer var målet at løsne den spændetrøje som henholdsvis livegenskabet og den stalinistiske planlægning havde lagt om samfundet for i stedet at sætte bor- 
gernes energi og initiativ fri. Samtidig indførtes retsstaten, således at loven kunne beskytte borgerne og deres ejendom mod vilkårlige bureaukratiske indgreb fra en politiseret administration. I et forsøg på at mobilisere offentligheden til støtte for reformerne og svække det intellektuelle forsvar for det gamle ophævedes forbuddet mod offentligt at give udtryk for kritiske opfattelser.

Gorbatjov har siden fået hele æren (eller skylden) for de reformer af Sovjetunionen, der førte til dens opløsning. Men grunden blev faktisk allerede lagt under den tidligere KGB-chef Jurij Andropovs (1914-84) kortvarige styre fra 1982 til 1984. Andropov døde efter kun 15 måneder ved magten, men erkendte med sin viden fra KGB's fortrolige indberetninger om landets virkelige tilstand behovet for radikale reformer. Han nåede næsten intet, men lagde grunden til den senere revolution ved at udnævne den efter sovjetiske forhold unge Mikhail Gorbatjov (f. 1931) til medlem af Politbureauet.

Efter et kort mellemspil under ideologen Konstantin Tjernenko (1911-85) blev han valgt til generalsekretær i 1985. Fælles for Gorbatjovs og Aleksander II's reformer var at ledelsen og magten stadig skulle hvile uindskrænket i hænderne på manden i toppen og hans tilhængere i forvaltningen. Demokratiseringen kom hurtigt til at udfordre såvel Aleksander II's som Gorbatjovs positioner og dermed opretholdelsen af det vældige multietniske rige. For at opnå en modernisering under ordnede former fandt begge ledere det lettere at lægge bånd på de anderledes tænkende (dissidenterne) end at acceptere en tilbundsgående demokratisering af hele samfundet. Deres tøven over for en reel demokratisering skyldtes at de blev konfronteret med oprør i de ikke-russiske randområder i samme øjeblik liberaliseringen tog fart.

I 1860'erne såvel som i 1980'erne stod det hurtigt klart at den yderste ring i imperiet kun kunne opretholdes med tvang. Der var samtidig parallelle årsager til at regimet ikke brød hurtigere sammen i de to situationer, end tilfældet var. Trods store forskelle mellem zarernes og Stalins moderniseringspolitik var der påfaldende ligheder mellem eliternes betingelser under zar-styret og i sovjettiden.

Peter den Store (1672-1725) havde efter sin sejr over Sverige ved Poltava i 1709 bestræbt sig på at åbne Rusland mod omverdenen, mens Stalin gjorde det modsatte. Men begge præsiderede over ekstremt brutale autoritære regimer, der flyttede befolkningen rundt med hensynsløs grundighed og effektivitet, en brutalitet der også gik ud over de eliter, der udførte politikken.

Derfor var eliterne lettede over den større tryghed de opnåede efter såvel Peters som Stalins død. Under zarerne indebar det garanti af ejen- 
domsretten, under Breznjnev tryghed i ansættelsen for bureaukratiet og stop for den hastige sociale mobilitet der havde karakteriseret Stalintiden. Med tiden fik eliterne smag for vestlig luksus og frihed, samtidig med at deres børn i stigende grad fik mulighed for at gøre sammenlignende studier i velstand og frihed $\mathrm{i}$ $\emptyset_{\text {st og Vest. }}$

Anskuet i det store perspektiv indebar Oktoberrevolutionen i 1917 i grunden ikke et egentligt brud med russisk tradition, alle blodsudgydelser og katastrofale ødelæggelser til trods. Snarere var der tale om en politisk ændring inden for rammen af én stor moderniseringscyklus i russisk historie, der i realiteten varede helt fra 1850'erne til 1970'erne. Ganske som Aleksander I's (17771825) indmarch i Paris 1814 markerede Ruslands succes i den første modernisering, markerede Sovjetunionens erobring af Berlin i maj 1945 imperiets status som en stormagt.

Russernes besættelse af Østberlin kom til at vare længere end Aleksander I's af Paris, men virkningen var den samme, indadtil såvel som udadtil. Indenrigspolitisk behøvede det herskende styre ikke længere at bekymre sig om herredømmets sikkerhed, og udadtil var prestigen sikret. Styret så derfor ingen grund til at løbe den risiko som radikale reformer altid indebærer i en stærkt centraliseret og autoritær stat, selv om mange havde en utryg fornem- melse af manglende effektivitet $\mathrm{i}$ landbrug og industri efter at fasen med ekstensiv genopbygning efter Anden Verdenskrigs ødelæggelser var overstået omkring 1960.

\section{Ineffektivitet og stagnation}

Ekstremt lav produktivitet prægede store sektorer af Sovjetunionens økonomi, en ineffektivitet der blev eksporteret til satellitstaterne i Østeuropa med de centraliserede plan$ø$ konomier, hvortil kom absurde spild i distribution og detailhandel. Op til halvdelen af kornet rådnede op under transporten fra producent til forbruger, mens ekspedienterne havde en helt urimelig magt i forhold til kunderne, der var reduceret til ydmyge ansøgere om varer fra butikkens hylder. Den generelt lave produktivitet sprang ikke alle iagttagere i øjnene, fordi den eksisterede sammen med fremragende resultater inden for militær- og rumfartsindustri.

I dag ved vi at disse sektorer repræsenterede et lukket kredsløb med særlige privilegier. Men selv de fremragende resultater her repræsenterede snarere håndværksmæssige éngangsprodukter end massefremstillet design som i USA.

Det forklarer delvis hvorfor resultaterne fra den sovjetiske rumindustri aldrig slog igennem uden for sin egen højt specialiserede sektor. Der er helt afgørende forskel på at kunne producere ét eksemplar og mas- 
sefremstille komponenterne. Kun våbenindustrien lykkedes det at masseproducere kvalitetsprodukter, en produktion der i vidt omfang har klaret omstillingen til fri konkurrence efter kommunismens sammenbrud.

Resultatet blev stagnations-perioden under Leonid Brezjnev fra 1964 til 1982. Denne stagnation svarede til Nikolaj I's regering fra 1825 til 1855 i slutningen af den forrige moderniserings-cyklus. Forsigtige reformer blev afløst af stivnet gammelmandsvælde og undertrykkelse.

Akkompagneret af militært praleri sakkede Rusland i 1970'erne såvel som i 1840'erne bagud i konkurrencen med mere demokratiske systemer der var i stand til at ændre sig selv indefra. 1800-tallets industrielle revolution svarer til informationsrevolutionen i 1970'erne og 1980'erne. Ingen af udfordringerne var lederne af det russiske imperium i stand til at besvare i tide. Derfor blev det nødvendigt at indføre en ny statsform. Boris Jeltsin lagde grunden til et nyt og demokratisk Rusland, men i Vladimir Putins (f. 1952) præsidentperiode fra 2000 er systemet blevet stabiliseret i form af en autoritær (og korrupt) markedsøkonomi styret fra Kreml og baseret på eksport af energiressourcer.

Indtil videre har denne styrkelse ført til en genoptagelse af truslerne mod naboerne i det såkaldte 'nære udland', især Georgien og de baltiske stater, men også trusler mod
Ukraine. Ved at spille kortet som leverandør af gas har Vladimir Putin indtil videre haft held med at føre Rusland tilbage i en dominerende stilling over for mange af de forhenværende sovjetrepublikker. Men ikke over for Øst- og Centraleuropa der er forholdsvis sikre som medlemmer af EU og NATO.

\section{Murens fald}

At Tysklands forening kun var mulig pga. opbruddet i de andre dele af det sovjetiske imperium, skal dog ikke forklejne betydningen af Murens fald i november 1989. Selv oplevede jeg den blandt vesttyske historikere på en konference om italiensk historie i den yderste vestlige udkant af Forbundsrepublikken, Trier. Midt under redegørelser for fascismens fald og borgerkrigen mellem partisanerne og tilhængerne af Salò-republikken 1943-45 blev der uro i salen.

Enkelte sneg sig ud og begyndte at følge begivenhederne i Berlin på fjernsynet. Og så blev vi målløse hængende foran apparatet. Ingen af os havde forudset DDR's pludselige sammenbrud, uanset hvor meget vi afskyede det østtyske regime. Dermed delte vi skæbne med næsten alle vestlige regeringsledere og deres efterretningstjenester, som heller ikke havde erkendt hvor slet det stod til med Østtysklands økonomi.

Siden indlemmelsen af DDR i Forbundsrepublikken i 1990 har vi fået 
den ene beretning efter den anden om Østtysklands dårlige økonomi. "Vi vidste godt, at det stod slemt til, men at det var så slemt, anede vi ikke", har omkvædet lydt fra de politisk og økonomisk ansvarlige. Det skal selvfølgelig tjene som undskyldning for daværende kansler Helmut Kohls (f. 1943) fejlslagne strategi med ikke fra starten at indrømme omkostningerne ved genforeningen.

Politisk var hans strategi dog rigtigere end flertallet af nølende socialdemokraters. SPD's kanslerkandidat i begyndelsen af 1990'erne, Oscar Lafontaine (f. 1943), i dag leder af efterfølgerpartiet til SED og PDS, die Linke, der med valgene i 2009 har etableret sig som det femte parti i Forbundsrepublikken, advarede om de økonomiske og sociale omkostninger ved foreningen. Han har fået endnu mere ret, end han kunne ane i 1990. Kansler Kohl indledte CDU's årskongres i 1995 med at indrømme at "arven efter 40 års DDR-diktatur var langt tungere end nogen havde forestillet sig". Selv de professionelle $ø$ konomer der burde have vidst bedre, delte den overoptimistiske vurdering af DDR's økonomiske potentiale.

Men er det virkelig sandt at vi ikke havde mulighed for at vide, hvor slemt det stod til, før Murens fald i 1990 ? Set fra i dag er det klart at problemet ikke var manglende data, men mentale filtre, der gjorde at politikere i Øst som i Vest ikke tog notits af de foreliggende oplysninger.
Krigsskadeserstatningerne til Sovjetunionen i årene efter Anden Verdenskrig svækkede Østtysklands $ø$ konomi. Men fra omkring 1970 bidrog Sovjetunionen økonomisk til opretholdelsen af sin østtyske koloni ved at levere råstoffer til under verdensmarkedspriserne og aftage industriprodukter som ikke kunne afsættes uden for Østblokken.

$\varnothing$ konomiske historikere er i dag enige om at indbyggede defekter ved den socialistiske planøkonomi senest fra midten af 1970'erne drev systemet til bankerot. Produktiviteten i DDR-virksomhederne sank støt, mens ingen hverken kunne eller ville undersøge om investeringer og resultater stod i et rimeligt forhold til hinanden.

Senest i begyndelsen af 1980'erne stod det ifølge den dengang ansvarlige DDR-økonom, Siegfried Wenzel, den kommunistiske ledelse klart at landet reelt var fallit og at det ville være næsten umuligt at redde situationen.

Trods denne indsigt skete der intet. Regeringen satsede på at videreforarbejde den billige sovjetiske olie og sælge den i Vesten for hård valuta, mens den dækkede det indenlandske energibehov med brunkul. Ud over en forfærdelig forurening kom der ingen vækst ud af det. Investeringerne ville have været nyttigere i andre industrier og førte kun til at udlandsgælden i 1986 var tre gange så høj som importindtægterne.

DDR's miserable økonomiske situ- 
ation var altså fra et tidligt tidspunkt kendt i Vest såvel som i Øst. Alligevel var der ingen i Politbureauet der reagerede på plankommissionens gentagne advarsler mod den truende fallit. Denne trussel fremgik ellers af de friserede officielle statistikker, hvis man læste dem omhyggeligt. Det blev senest klart i slutningen af 1970'erne da Banken for International Betalingsudligning i Genève begyndte at føre regnskab over østblokstaternes udlandsgæld.

For opmærksomme læsere var der i virkeligheden også mange andre indicier på regimets svaghed. Problemet er blot at det er meget lettere at tolke dem rigtigt i dag, hvor vi kender udgangen på historien.

Læst med vores nuværende viden er det let at se at partiorganet Neues Deutschland blev præget af en stadig mere defensiv tone. Henvisningerne til marxismen blev mere og mere rituelle, også i propagandaen. Undertrykkelsesapparatet var fortsat brutalt, men statssikkerhedstjenesten Stasi tillod oppositionen noget friere tøjler fra midten af 1980 'erne.

Men at det var udtryk for tvivl og usikkerhed og ikke gradvis 'normalisering' er lettere at se i dag end dengang. Tværtimod udtrykte ledende vesttyske politikere støtte til den østtyske stat, som Tony Judt (f. 1948) påviser i sin glimrende bog om Europas historie efter 1945 (Postwar, 2006). Og selv den stærkt antikommunistiske leder af CSU, Franz Joseph Strauss (1915-88), var ansvarlig for formidlingen af et stort lån til DDR.

Trods alle tilgængelige informationer var der praktisk taget ingen $\mathrm{i}$ Vesten som forestillede sig et totalt sammenbrud for den østtyske stat. Det gjaldt for det vesttyske beslutningstagermiljø såvel som for CIA, i hvert fald på de højere niveauer i organisationen.

Men når sandheden skal frem, gælder det også for næsten alle os andre. Fantasien rakte ikke langt, når det gjaldt de kommunistiske regimer. Desuden skal man ikke glemme at det passede mange ganske godt med delingen af Tyskland. Man syntes ganske vist nok at det var synd for østtyskerne, at de skulle betale prisen for verdens stabilitet, men det var der i den realt eksisterende verden med atomvåbnenes terrorbalance ikke meget at gøre ved.

Jeg selv var så sent som i 1988 med til at skrive en bog om tysk historie. Her tilsluttede vi os den franske intellektuelle André Malrauxs (1901-76) og den italienske politiker Giulio Andreottis (f. 1919) vittighed om at Tyskland er så god en ting, at det gælder om at have så mange som muligt af dem - en formulering som også den daværende danske statsminister Poul Schlüter (f. 1929) efter sigende nåede at fremføre, inden DDR forsvandt.

At DDR var bankerot, anede vi måske, men tænkte på den anden side at det blev kompenseret af den melankolske skønhed ved de sociali- 
stiske lande, hvor alting var gået i stå i nostalgisk, lortebrun 50'er-stilstand.

\section{Nye skillelinjer}

Omvæltningerne i 1989 kom overraskende, og i dag er det næsten umuligt at forestille sig hvilket brud med de trygge og velkendte skillelinier fra den kolde krig, det betød.

Set i det lys er det glædeligt - og i grunden overraskende - at så mange af de øst- og centraleuropæiske lande har fundet tilbage til Europa som medlemmer af EU. Det tog tid ja, men er lykkedes. Ikke uden problemer, slet ikke. Lande som Rumænien og Bulgarien er givetvis optaget før deres økonomier og retsvæsen var klar til det.

Her må vi blot håbe at reformprocessen fortsætter, selv om guleroden om medlemskab ikke længere kan bruges til at tvinge dem til reformer. Ungarn er i en håbløs forfatning, men det skyldes i høj grad at landets politikere ikke har været i stand til at samarbejde for at hele den splittelse, som den sovjetiske besættelse medførte.

Trods alle økonomiske problemer må man i det mindste glæde sig over at forholdene er nogenlunde regulerede for de nationale mindretal, hvoraf flertallet er ungarske som følge af de hårde og ugunstige grænsedragninger efter Første Verdenskrig. Ikke perfekte, som striden om en slovakisk sproglov vendt mod det store ungarske mindretal fra august $\mathrm{i}$ år viser. Men alligevel bedre end nogensinde før. Med undtagelse af de mange millioner romaer hvis udsatte situation repræsenterer den største udfordring for EU's mindretalsbeskyttelsespolitik.

Nationalismens spøgelse er ikke forsvundet, slet ikke. Jeg har slet ikke nævnt krigene i Jugoslavien som er det sted, hvor forudsigelserne om nationalistiske borgerkrige som følge af kommunismens fald kom til at slå til.

Den førnævnte polske dissident Adam Michnik forudsagde det i 1990 med et elegant spil på Lenins (1870-1924) formulering fra 1916 om 'Imperialismen som kapitalismens højeste stadium'. I stedet skrev han ironisk i en artikel der bl.a. blev bragt på dansk i det længst forsvundne tidsskrift Omverden i 1990, at 'Nationalismen er kommunismens højeste stadium'. Med det mente han at det kommunistiske system fungerede som en dybfryser, der holdt de nationale konflikter nede, men at de ville bryde ud i lys lue i samme øjeblik diktaturet brød sammen.

Denne forudsigelse gik i opfyldelse i Jugoslavien og i Kaukasus. Men indtil videre kun dér. Den svenskdanske Ruslandsforsker, Märta-Lisa Magnusson (f. 1950), organiserede med sikker næse for aktualitet en rejse for danske udenrigspolitisk interesserede til Georgien, Armenien og Aserbajdsjan i november-december 1989 . 
Her blev vi vidner til opløsningen af det sovjetiske imperium. Allertydeligst da vi overværede hvorledes et helt regiment af unge aserbajdsjanere i lufthavnen i Baku deserterede på vej til militærtjeneste i Polen. De undslap gennem vinduerne og blev i busser af den nationale front kørt tilbage til hovedstaden. Kun for at blive sendt i krig mod armenierne om enklaven Nagorno-Karabakh.

\section{Glæde trods alt}

Denne konflikt er som så mange andre stadig ikke løst. Men overordnet set er der alligevel grund til stort set at glæde sig her tyve år efter kommunismens og Murens fald. Et fald som næsten ingen havde forudset og langt fra alle glædede sig over, mens det skete.

Fx den daværende præsident $\mathrm{i}$ Frankrig, François Mitterrand, der prøvede at holde de østeuropæiske lande ude af EU med en særlig konføderation oprettet til formålet. $\mathrm{Og}$ krævede indførelse af en økonomisk og monetær union i EU som betaling for at acceptere samlingen af Tyskland. Det gik vist hen over hovedet på de mange velmenende danskere der stemte nej til Maastrichttraktaten, samtidig med at de glædede sig over Murens fald og ønskede $\varnothing$ østeuropa med i EU. Heller ikke Storbritanniens Margaret Thatcher (f. 1925) var entusiastisk over Tysklands forening og modarbejdede den længst muligt. Men det er i dag alt sammen overstået, past history som de siger på amerikansk. Men hvor verden bevæger sig hen, er svært at sige. Tysklands kansler, Angela Merkel (f. 1955), der selv har oplevet kommunismen, har ret $i$ at vi stadig lever i eftervirkningerne af kommunismens sammenbrud.

George Bush den ældre (f. 1924) fik ikke ret i ankomsten af en ny verdensorden som han proklamerede med angrebet på Irak i 1991; Osama bin Laden (f. 1955) heller ikke med sit angreb på World Trade Towers i 2001. Bric-landene Brasilien, Rusland, Kina og Indien er stærkt på vej og har sammen med andre lande fået formaliseret deres indflydelse gennem G-20.

Men trods al svækkelse af USA er det for tidligt at afskrive denne stormagt, selv om landet er blevet mere multilateralt. Formentlig er det også for tidligt at afskrive EU nu hvor Unionen og Europa for første gang er lige ved at være identiske.

Om marxismen får et come back som politisk teori i kraft af finanskrisen bliver spændende at se. Men kommunismen gør næppe.

Uffe Østergård, professor i europaisk og dansk historie, International Center for Business and Politics, CBS.

Litteraturliste til artiklen kan fås ved at sende en mail til brita@udenrigs.dk 